\section{'Naoussa' Pear}

\author{
Thomas Sotiropoulos ${ }^{1}$ \\ Department of Deciduous Fruit Tree Growing in Naoussa, Institute of Plant \\ Breeding and Phytogenetic Resources, Hellenic Agricultural Organization \\ "Demeter," R.R. Station 38, 59035 Naoussa, Greece
}

\section{Nikolaos Koutinas and Anastasia Giannakoula \\ School of Agricultural Technology, Food Technology and Nutrition, Alexander Technological Educational Institute of Thessaloniki, P.O. Box 141, 57400, Thessaloniki, Greece}

Additional index words. cultivar description, fruit breeding, Pyrus communis
Naoussa is a late-July maturing pear (Pyrus communis L.) cultivar originating from a cross between the pear cultivars Kristali and Coscia. Annual fruit production per tree of 'Naoussa' grafted on quince BA 29 rootstock over a period of 5 years (from the 5 th until the 9 th year of the trees) averaged $63.4 \mathrm{~kg}$. Fruits are pyriform with a mean equatorial diameter of $71 \mathrm{~mm}$, a mean length of $86 \mathrm{~mm}$, and a mean weight of $162 \mathrm{~g}$. The flesh is yellow-white, juicy, flavorful, and aromatic, with very few stone cells. The skin is smooth, free of russeting, and has no tendency to become waxy in storage. Fruits mature on the tree in late July, coincide with 'Kalliopi', 'Coscia', and 'Tosca', are $12 \mathrm{~d}$ earlier than 'Santa Maria' and are about $42 \mathrm{~d}$ earlier than 'Williams'. The fruits are used mainly for fresh consumption. Two harvests are required under moderately cropped conditions. Total soluble solids, firmness, and total titratable acidity were not different between 'Naoussa' and 'Coscia'. After harvest, fruits can be kept at room temperature for about 2 weeks, or they can be refrigerated in common cold storage rooms at $1{ }^{\circ} \mathrm{C}$ for about 3 months.

\section{Origin}

In Greece, the total pear production in 2013 was $65,000 \mathrm{t}$ and acreage was 4,500 ha (FAO, 2013). The main pear cultivars grown in Greece are Kristali, Kontoula, and Williams. 'Naoussa' was derived from a cross between the pear ( $P$. communis) cultivars Kristali and Coscia. The creation of this cultivar was done in the Department of Deciduous Tree Fruit Growing in Naoussa. The description was done in the previously mentioned Department and in private orchards in the same area (northern Greece, long. $22^{\circ} 12^{\prime} 0^{\prime \prime} \mathrm{E}$; lat. $40^{\circ} 29^{\prime} 04^{\prime \prime} \mathrm{N}$; elevation $225 \mathrm{~m}$ ). The mean maximum temperature of the experimental area is $38{ }^{\circ} \mathrm{C}$ in July, whereas the mean minimum temperature is $-7{ }^{\circ} \mathrm{C}$ in January (means of 10 years). The objective of this research was to give

Received for publication 24 Feb. 2016. Accepted for publication 11 Mar. 2016.

${ }^{1}$ Corresponding author. E-mail: thosotir@otenet.gr. information about the new pear cultivar Naoussa and to compare it with the cultivar Coscia that matures at the same period.

\section{Description and Performance}

Tree. The evaluation was performed in a private orchard. The experimental trees of both cultivars were of the same age, planted in the same orchard at distances $4 \times 2 \mathrm{~m}$ apart and trained as a palmette. Productivity data reported are means of 25 trees ( 5 replications $\times 5$ trees) for 5 years, analyzed as a randomized complete block design. All other fruit characteristics reported were based on a random sample of 30 fruit selected from all of the fruits collected from the 25 trees in each year. The significance of the differences between means was evaluated by using Fisher's $t$ test analysis of variance at $P \leq 0.05$ carried out by SPSS Version 17 (SPSS Inc., Chicago, IL).

When scions were grafted on 'Provence Quince' (BA 29; Cydonia oblonga Mill.) rootstock, trees were moderately vigorous with a fairly upright habit. The graft compatibility of scion and rootstock in the combination 'Naoussa'/BA 29 was satisfactory. Scaffold branch angle was 37 to $50^{\circ}$ from vertical. Trees were grafted in situ and started producing fruits 2 to 3 years later. Maximum production was reached at the 7 th year. When trees set heavy crops, thinning (to single king fruits) was necessary to improve fruit size and to avoid biennial bearing. Leaf nutrient concentrations were within the range proposed by Bergmann (1988); more specifically: N 2.60, P $0.24, \mathrm{~K} 1.89, \mathrm{Ca} 1.74, \mathrm{Mg}$ 0.29 (mg. ${ }^{-1}$ dry weight); Mn 56, Zn 24, Cu 7, and B $29\left(\mu \mathrm{g} \cdot \mathrm{g}^{-1}\right.$ dry weight). Over a period of 5 years (from the 5 th till the 9 th year of the trees), the annual fruit production per tree of 'Naoussa' grafted on BA 29 rootstock averaged $63.4 \mathrm{~kg}$, and was higher than 'Coscia' (Table 1). Yield efficiency of the cultivar Naoussa was also higher. Bark color of 1- to 2-year-old shoots is gray. Branch lenticels are oval, $0.5-0.7 \mathrm{~mm}$ in diameter, and gray white. Mixed buds are born on 1-year-old shoots and spurs generally are found on 2 -year-old or older shoots.

Leaves. Leaf measurements were made with a portable leaf area meter AM 300 (ADC Bioscientific Ltd., Hertfordshire, England). The leaves are oval with the following dimensions: length of $85 \mathrm{~mm}$, width of $71 \mathrm{~mm}$, leaf area of $4321 \mathrm{~mm}^{2}$, and leaf perimeter of $266 \mathrm{~mm}$. Leaf surfaces are smooth, the dorsal surface is shiny and there is no pubescence. The petioles are yellow green, averaging $38 \mathrm{~mm}$ long and $1.9 \mathrm{~mm}$ wide. Leaf fall occurs in late November.

Flowers. The trees require cross-pollination. Flowering period starts on 27 Mar. (mean of 5 years) and has a good overlap with the cultivars Abate Fetel, Conference, Comice, Highland, and Beurre Hardy. Flowering of the cultivar Coscia starts at 25 Mar. Cross compatibility studies showed that suitable pollinizers of Naoussa include the cultivars Highland and Kalliopi (Sotiropoulos et al., 2009). Flowers have white oval petals and pink anthers. Stamens are white and 4 to $5 \mathrm{~mm}$ long. The pistils are $5-6 \mathrm{~mm}$ in length, rounded, fused at the base, and they are at the same height as the stamens. The pollen is yellow.

Fruits. Measurements reported were from samples taken at the first harvest. Mature fruits of the cultivars Naoussa and Coscia were evaluated immediately after harvest. Fruits are pyriform with a mean equatorial diameter of $71 \mathrm{~mm}$, mean length of $86 \mathrm{~mm}$, and mean fruit weight of $162 \mathrm{~g}$ (Table 1; Fig. 1). Fruit weight and fruit diameter of 'Naoussa' were higher than 'Coscia'. The flesh is yellow white, juicy, flavorful, aromatic, and with very few stone cells. The skin is smooth, free of russeting, and has no tendency to become waxy in storage. The pedicel of the fruit is green and medium in length $(\approx 35 \mathrm{~mm})$. The calyx tends to be persistent, inconspicuous, and apressed to the pistillate end at maturity. Fruit mature on the tree in late July, coincident with 'Kalliopi' (Sotiropoulos et al., 2009), 'Coscia', and 'Tosca', $12 \mathrm{~d}$ earlier than 'Santa Maria', $17 \mathrm{~d}$ earlier than 'Kristalli', and about $42 \mathrm{~d}$
Table 1. Yield, yield efficiency, fruit weight, fruit equatorial diameter, and fruit length of the pear cultivars Naoussa and Coscia over a period of 5 years.

\begin{tabular}{|c|c|c|c|c|c|}
\hline Cultivar & $\begin{array}{c}\text { Yield } \\
\text { (kg/tree) }\end{array}$ & $\begin{array}{l}\text { Yield efficiency } \\
{[\mathrm{kg} / \text { tree to trunk }} \\
\text { cross-sectional } \\
\left.\text { area }\left(\mathrm{cm}^{2}\right)\right]^{\mathrm{z}}\end{array}$ & Fruit $\mathrm{wt}^{\mathrm{y}}(\mathrm{g})$ & $\begin{array}{c}\text { Fruit } \\
\operatorname{diam}^{\mathrm{y}}(\mathrm{mm})\end{array}$ & $\begin{array}{c}\text { Fruit } \\
\text { length }^{\mathrm{y}}(\mathrm{mm})\end{array}$ \\
\hline Naoussa & $63.4 \mathrm{a}^{\mathrm{x}}$ & $0.74 \mathrm{a}$ & $162 \mathrm{a}$ & $71 \mathrm{a}$ & $86 a$ \\
\hline Coscia & $51.5 \mathrm{~b}$ & $0.66 \mathrm{~b}$ & $139 \mathrm{~b}$ & $54 \mathrm{~b}$ & $80 \mathrm{a}$ \\
\hline
\end{tabular}

${ }^{\mathrm{z}}$ Means of 25 trees ( 5 replications $\times 5$ trees) for 5 years.

${ }^{\mathrm{y}}$ Means of 30 fruits from 25 trees ( 5 replications $\times 5$ trees) for 5 years. Fruits from all trees were pooled.

${ }^{\mathrm{x}}$ Means followed by the same letter in the same column are not significantly different (Fisher's $F ; P \leq 0.05$ ). 
earlier than 'Williams'. In order all the fruits to have high quality for consumption, two harvests are required under moderately cropped conditions with $\approx 1$-week interval. When harvested, the skin is green or light greenyellow. Total soluble solids (measured with the Atago PR-1 electronic refractometer; Atago Co. Ltd., Tokyo, Japan), flesh firmness (as measured by an Effegi penetrometer using an 8-mm probe; Effegi, Milan, Italy),

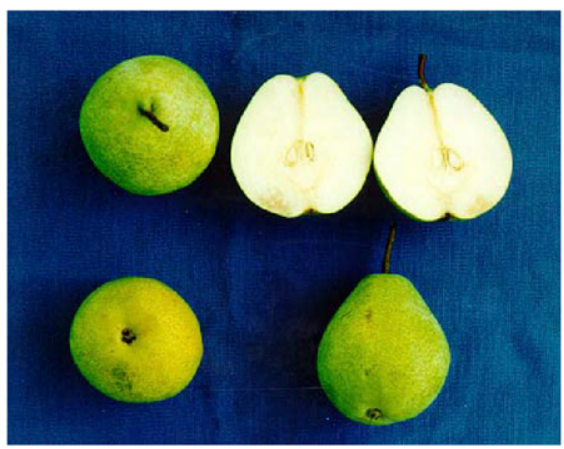

Fig. 1. Fruits of the pear cultivar Naoussa. and total titratable acidity of the juiced flesh as described by Koukourikou-Petridou et al. (2007) were not different among cultivars (Table 2). Ascorbic acid content (measured by oxalic acid $1 \%$ ), total antioxidant capacity, and total phenols (Singleton et al., 1999) were not different among cultivars (Table 2). Total phenols were expressed as milligrams gallic acid equivalents per gram fresh weight (FW). Sample extracts were analyzed for their antioxidant activity by the ferricreducing antioxidant power (FRAP) assay (Benzie and Strain, 1996) using a Camspec M106 spectrophotometer (Camspec Analytical Instruments Ltd., Leeds, UK) at $593 \mathrm{~nm}$. The FRAP values of the samples were expressed as micromolars L-ascorbic acid equivalents per gram FW. After harvest, fruits can be kept at room temperature for about 2 weeks, or they can be stored successfully for up to 3 months in common cold storage rooms at $1{ }^{\circ} \mathrm{C}$. The fruits are used mainly for fresh consumption, but also used for preparing jam and marmalade.

From our observations, 'Naoussa' has the same degree of resistance with the cultivar Coscia to pear scab (Venturia pirina Aderh.)

Table 2. Total soluble solids, flesh firmness, total titratable acidity, ascorbic acid, total antioxidant capacity, and total phenols in fruits of the pear cultivars Naoussa and Coscia over a period of 5 years.

\begin{tabular}{|c|c|c|c|c|c|c|}
\hline Cultivar & $\begin{array}{c}\text { Total soluble } \\
\text { solidsz }(\%)\end{array}$ & $\begin{array}{l}\text { Firmness }{ }^{\mathrm{z}} \\
\left(\mathrm{kg} \cdot \mathrm{cm}^{-2}\right)\end{array}$ & $\begin{array}{c}\text { Total titratable } \\
\text { acidity }^{\mathrm{z}}(\%)\end{array}$ & $\begin{array}{l}\text { Ascorbic acid } \\
\text { (mg. } \mathrm{g}^{-1} \text { fresh } \\
\text { weight) }\end{array}$ & $\begin{array}{c}\text { Total antioxidant } \\
\text { capacity } \\
\text { ( } \mu \text { mol AAE } / g \\
\text { fresh weight) }\end{array}$ & $\begin{array}{c}\text { Total phenols } \\
\text { (mg GAE/g } \\
\text { fresh weight) }\end{array}$ \\
\hline$\overline{\text { Naoussa }}$ & $12.04 \mathrm{a}^{\mathrm{x}}$ & $4.55 \mathrm{a}$ & $0.94 \mathrm{a}$ & $0.10 \mathrm{a}$ & $9.68 \mathrm{a}$ & $0.49 \mathrm{a}$ \\
\hline Coscia & $11.92 \mathrm{a}$ & $4.60 \mathrm{a}$ & $0.91 \mathrm{a}$ & $0.09 \mathrm{a}$ & $10.16 \mathrm{a}$ & $0.46 \mathrm{a}$ \\
\hline
\end{tabular}

$\mathrm{AAE}=$ ascorbic acid equivalents; GAE $=$ gallic acid equivalents.

${ }^{\mathrm{z}}$ Means of 30 fruits from 25 trees $(5$ replications $\times 5$ trees) for 5 years. Fruits from all trees were pooled.

${ }^{\mathrm{y}}$ Measurement of 2 years. Same number of fruits as above.

${ }^{\mathrm{x}}$ Means followed by the same letter in the same column are not significantly different (Fisher's $F ; P \leq 0.05$ ). and pear psylla (Cacopsylla pyricola Forster). 'Naoussa' like its parent 'Coscia' is relatively tolerant to fire blight [Erwinia amylovora (Burrill) Winslow et al.].

In conclusion, 'Naoussa' is a promising pear cultivar due to its fruit quality attributes and can be considered as an alternative to other cultivars that mature at the same period, e.g., 'Coscia'.

\section{Availability}

'Naoussa' pear has not registered yet in the official list of the Greek Ministry of Rural Development and Food. Propagation wood is available from the Institute of Plant Breeding and Phytogenetic Resources, Department of Deciduous Fruit Growing in Naoussa.

\section{Literature Cited}

Benzie, I. and J. Strain. 1996. The ferric reducing ability of plasma (FRAP) as a measure of 'antioxidant power': The FRAP assay. Anal. Biochem. 239:70-76.

Bergmann, W. 1988. Ernahrungsstorungen bei Kulturpflanzen. 2nd ed. Gustav Fischer, Jena, Germany.

Food and Agriculture Organization (FAO). 2013. 25 Nov. 2015. <http://faostat.fao.org >.

Koukourikou-Petridou, M., D. Voyatzis, D. Stylianidis, T. Sotiropoulos, and I. Therios. 2007. Effects of some growth regulators on pre- and after-storage quality of Red Chief Delicious apples. Eur. J. Hort. Sci. 72:8-11.

Singleton, V.L., R. Orthofer, and R.M. LamuelaRaventos. 1999. Analysis of total phenols and other oxidation substrates and antioxidants by means of Folin-Ciocalteu reagent. Methods Enzymol. 229:152-178.

Sotiropoulos, T., G. Syrgiannidis, N. Koutinas, A. Petridis, and D. Almaliotis. 2009. 'Kalliopi' summer pear. HortScience 44:2015-2016. 